\title{
Potential Investigation of B3 Waste (Used Oil) of Motorcycle as Alternative Diesel Fuel
}

\author{
Yohanes ${ }^{\text {a,* }}$, and Artinah Rukmana ${ }^{\text {a,* }}$ \\ a) Laboratory Technology Production, Mechanical Engineering Department, Universitas Riau, Indonesia \\ *Corresponding author: yohanes@lecturer.unri.ac.id, artinah.rukmana3418@student.unri.ac.id
}

\section{Paper History}

Received: 13-January-2020

Received in revised form: 21-May-2020

Accepted: 30-July-2020

\begin{abstract}
The waste or used engine oil is categorized as a Hazardous and Toxic Wastes (bahan berbahaya dan beracun/B3). However, it may have a great potential such as the alternative fuel. This study is proposed to investigate the potential of waste/used oils of motorcycle for diesel fuel. This research used Strengths, Weaknesses, Opportunities and Threats (SWOT) analysis and Quality Function Deployment (QFD) methods to investigate the potential of the used oils of motorcycle. From analysis result based the SWOT and QFD this was revealed the waste or used oil of motorcycle having an opportunity for alternative diesel engine fuel, which it has a positive impact both in economic and environmental terms. Based the test result of fuel consumption between diesel and waste or used oil in terms of costs obtained Rp. 2,532.00/KW for diesel fuel consumption and Rp.787.00/KW for waste or used oil. Therefore, the waste or used oil of motorcycle has potential become diesel fuel. However, it need further research to investigate the efficiency of the diesel engine performances.
\end{abstract}

KEY WORDS: Waste or Used Oil, SWOT Analysis, QFD Method, Diesel Fuel.

\section{NOMENCLATURE}

$\begin{array}{ll}\rho & \text { Density }\left(\mathrm{kg} / \mathrm{m}^{3}\right) \\ v & \text { Viscosity }\left(\mathrm{m}^{2} / \mathrm{s}\right) \\ t & \text { Time (Sekond) } \\ X & \text { Factors Matrix Internal } \\ Y & \text { Factors Matrix External } \\ n & \text { Large Sample } \\ N & \text { Large Populations }\end{array}$

df $\quad$ Degrees of Freedom

$r \quad$ Price Critical of Products Moment

\subsection{INTRODUCTION}

The waste oils B3 (used oil) has a viscosity that is high enough, that can be used as diesel fuel and burns easily in the combustion chamber of diesel engine [1]. According Widiyanto [2] the utilization of used oil as auxiliary blasting fuel (ANFO) has environmental benefits, which reduce waste of $3,585,233.33$ liters of used oil and save on fossil energy sources (solar) amounting to $3,887,602.41$ in the solar utilization activities for 4 years. Therefore, utilization of used oil waste has environmental benefits, and economic and social, thereby supporting sustainable development in the mining sector [2].

From the results of field observations indicate a very specific ratio of the price comparisons used oil usage with solar usage efficiency ratio due to fuel consumption of diesel engine. The diesel engine oil is more profitable than simply sell its to a receiver of any used oil. So, in this study will be identified the potential utilization of used oil waste motorcycles. The methods to identifying potential of used oil waste are the SWOT analysis and Quality Function Deployment (QFD).

The SWOT analysis is a method to determine the strengths, weaknesses, opportunities and threats of internal and external environment of a project [3-5]. Examples of the application of SWOT analysis are Yiu et al. [6], they investigated the potential of waste cooking oil and obtained positive impacts on the environment as well as offering direct and un-direct jobs. More, Septiawan et al. [7] conducted the analysis of the environmental management of palm oil mill in PT. Smart Tbk, Indonesia. They found the implementation of sustainable palm oil, which resulted in a strategy to optimize the performance of environmental management that can continuously enhanced one of them, optimizing the reduction of waste generation B3, and hold regular training related to environmental management improving personnel competence [7].

This paper proposed to investigate the potential of waste or used oil of motorcycle, which employed SWOT analysis and QFD methods. This research is helpful to know the potential of the B3 waste such as waste or used oil of motorcycle as an alternative fuel for diesel motors generate small-scale electric energy. 


\subsection{FUNDAMENTAL THEORY}

The hazardous and toxic waste (B3) is the residue of a business or activity that contain hazardous materials or toxic, which can pollute and be harmful environment, health, survival of humans and other living organisms [8]. Consequently, the used oil waste poses a risk to the environment and health and needs to be managed wisely. One way is to process the waste to be useful or recycled. The SWOT and QFD methods can be uses to analysis the potential of waste or used oil of motorcycle.

The SWOT analysis includes measuring to identify the strengths, weaknesses, opportunities, and threats that determine performance of company. External Information of opportunities and threats can be obtained from many sources, including customers, government documents, suppliers, banks and other colleagues in the company [4-5]

a. Internal factors

For internal factor or factors originating from within consists of two points, namely the strengths and weaknesses. Both of which will impact better in a study when the power is greater than a weakness.

b. External factors

The opportunities and threats this course will give you the data that must be included in the research journal that will produce a strategy to deal with it. SWOT analysis processing strategy example can be seen in Figure 1 [9].

\begin{tabular}{|c|c|c|c|c|}
\hline & Strategy Factor & Weight & Rating & Score \\
\hline \multirow{2}{*}{ 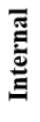 } & Strength (S) & $\mathrm{S} 1(0,0-1,0)$ & S2 (1-4) & $\mathrm{S} 1 \mathrm{xS} 2=\mathrm{S} 3$ \\
\hline & Weakness (W) & W1 $(0,0-1,0)$ & W2(1-4) & $\mathrm{W} 1 \mathrm{xW} 2=\mathrm{W} 3$ \\
\hline \multirow{2}{*}{ 馬 } & Opportunity (O) & $\mathrm{O} 1(0,0-1,0)$ & $\mathrm{O} 2(1-4)$ & $\mathrm{O} 1 \mathrm{xO} 2=\mathrm{O} 3$ \\
\hline & Threats (T) & T1 $(0,0-1,0)$ & T2 (1-4) & $\mathrm{T} 1 \times \mathrm{T} 2=\mathrm{T} 3$ \\
\hline
\end{tabular}

Figure 1: SWOT Processing Strategy

The QFD concept invented Japan in 1960 after the World War 2 is completed. The QFD concept used Japan to imitate the product [10]. The QFD consists of several main activities: elaboration of consumer requirements; elaboration of measurable quality characteristics; determining the relationship between quality needs and quality characteristics; the application based on a certain number of each characteristic quality; the integration of quality characteristics into the product; production design and product quality control [10].
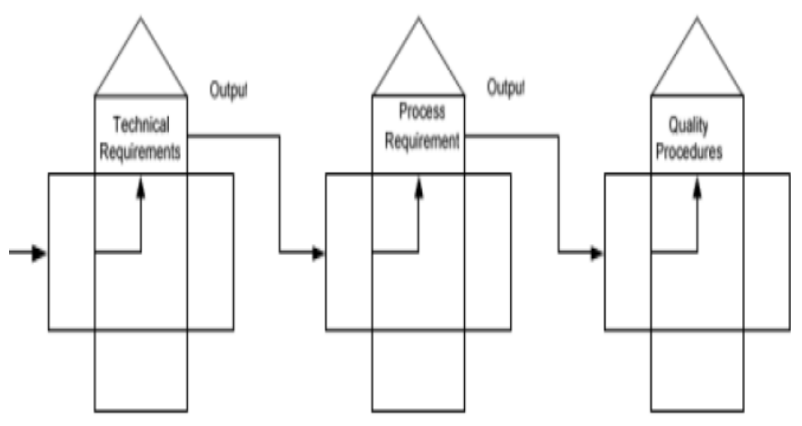

The QFD stages, namely: guaranteeing the product quality; elaboration of consumer requirements through consumer opinion (questionnaire, survey); elaboration of the characteristics of consumer needs; making the House of Quality matrix [11]. In line with the times, the matrix contains the needs of customers on the left and the technical characteristics of the upper. Each section of a matrix contains important things (Figure 2) [12].

\subsection{RESEARCH METHODOLOGY}

The waste/used oil is dangerous for the environment after a certain period of time. Recycling of waste oil by refining and turning it into fuel that is very important in terms of environmental protection. After the waste oil is converted into fuel, waste oil can be used as fuel in an internal combustion engine. In the recycling process, waste oil is exposed to various processes, and then used as fuel or they are converted into various chemicals to minimize the harmful effects of this waste [11].

Research approach is to use mixed methods, in which the quantitative method is the main approach to research and methods qualitative included to supplement and refine discusion research results. The study was divided into three stages: (1) analyze the potential of the B3 waste oil using the SWOT analysis, (2) investigation of potential waste used oil to alternative fuel substitute for diesel fuel using the QFD and (3) compare the economic uses between waste oil fuel and diesel [4].

Once the internal and external matting factors are compiled, then the result are put in a quantitative model, which the SWOT matrix to formulate a competitive corporate strategy. A phase of analyzing potential waste oil was employed a SWOT analysis, which was looked for internal and external solutions to these problems. The purpose and benefits of SWOT analysis are to combine four factors or composition precisely on strengths, overcoming weakness, find opportunities and a strategy to face a variety of threats. Stages of a SWOT analysis for this study can be seen in Figure 3.

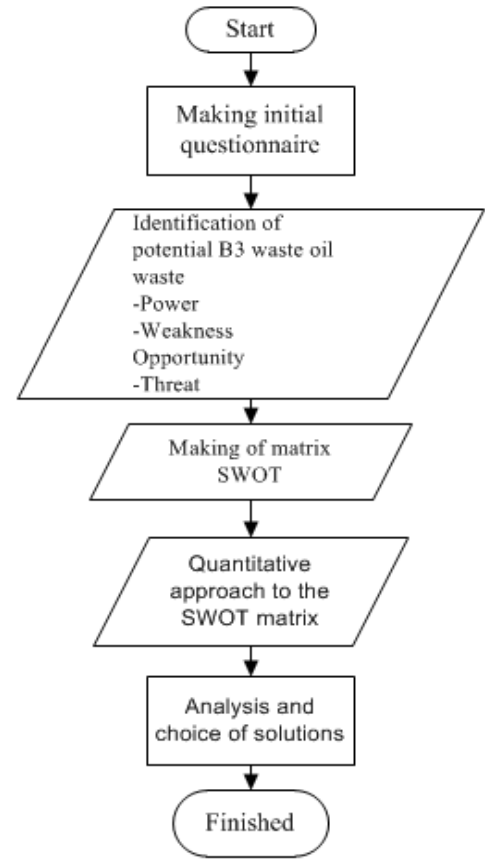

Figure 3: SWOT analysis flowchart 


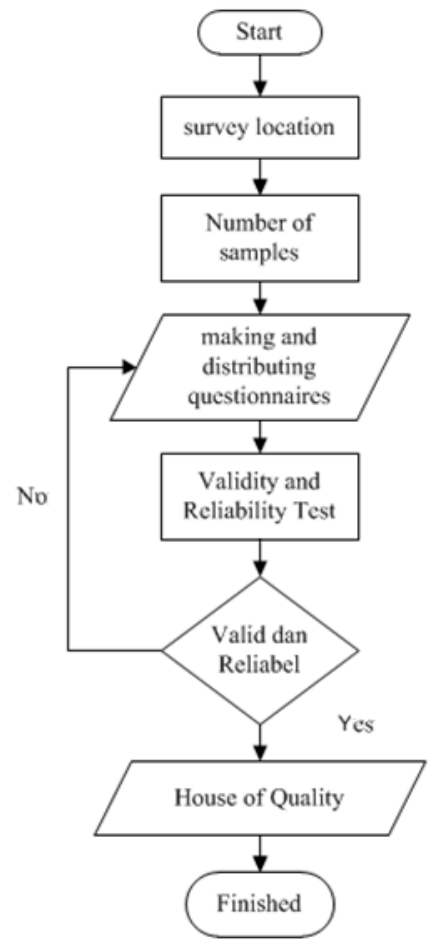

Figure 4: The QFD method flowchart

Furthermore, the used oil of motorcycle fuel consumption was compared to diesel fuel. The comparison of expenditure was used for the engine to operate for one hour with a power output of $3 \mathrm{KW}$. A test equipment setup using diesel engines made by Yohanes et al. [1]. Setting testing diesel motor can be seen in Figure 5.

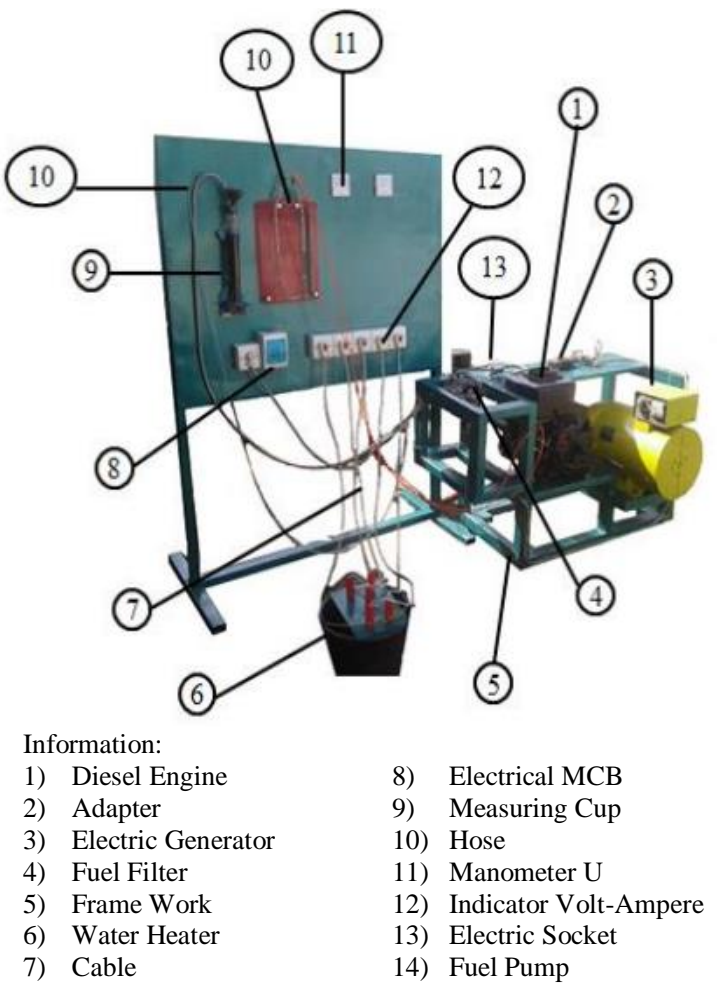

Figure 5: Diesel Engine [1]
The SWOT analysis can be obtained in terms of positive and negative B3 waste utilization for motorcycle used oil. Then the data analysis was performed by arranging of the House Of Quality (HOQ) compiled a phase of Quality Function Deployment. In the process of making the quality of House required the creation of a questionnaire or interview the customer. Stages of preparation HOQ analysis for this study can be seen in Figure 4.

For identification of the used oil performances do in Mineral Nature Materials Technology Laboratory of Chemical Engineering, University of Riau, and Pekanbaru, Indonesia. Characteristics of the fuels being tested are the viscosity and density of used oil motorcycle. The purpose for the identification of the viscosity and density can made the combustion process running optimally.

a. Viscosity

Viscosity shows resistance to the flow of fluid. The higher the viscosity of the fuel, the more difficult the fuel was injected [13].

$$
v=\frac{t_{\text {oli }} \times \rho_{\text {oli }}}{t_{\text {air } x \rho_{\text {air }}}} \mu_{\text {air }}
$$

b. Density

Mass type shows the magnitude of the ratio between the mass of a fuel volume [14].

$$
\rho=\frac{m_{\text {air }}}{v}
$$

\subsection{RESULTS AND DISCUSSION}

In this study, the location of questionnaires conducted in Pekanbaru city of Riau. In this study have been determined respondents selected in a motorcycle repair shop, both public and official in the city of Pekanbaru. The number of respondents who deployed as many as 415 of the mechanical and customer workshops. Because the population of more than 100 people then sampled $10 \%$. So the determination of the number of samples is based on probability sampling technique is simple random sampling method (random sample), so the formula according Suharsimi [15].

$$
N=10 \% \times n
$$

From calculation to determine the number of samples it obtained 42 samples or 42 questionnaires filled out by respondents. SWOT analysis of data obtained through the first questionnaire to the authorized repair shop located in the area of Riau pekanbaru. Data from the questionnaire have the appropriate level of interest for these consumers. SWOT analysis on the data collection has 4 factors that will become an important reference in the manufacture of a questionnaire on Quality Function Deployment (QFD). SWOT analysis of the decision matrix is strengthening research on the potential for B3 waste (used oil).

To get the results of using the method of SWOT analysis required data processing of the questionnaire in order to get the results of a quantitative approach in Figure 6.

The results of the processing of a SWOT analysis it is positioned on the first quadrant in which recommendation tactics award is Progressive $(+,+)$ this position proves that with the diesel engine modifications and accompanied by the B3 waste used oil will be increasingly clear that there are great opportunities in the harnessing kan These B3 waste as an 
(C) 2012 ISOMAse, All rights reserved

alternative fuel that has a positive impact both in economic and environmental terms.

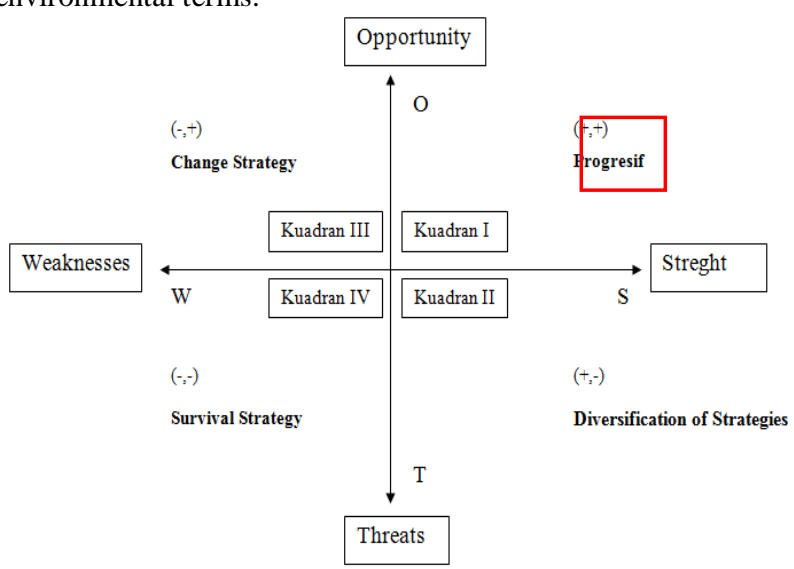

Figure 6: SWOT Analysis Processing

\subsection{Results Identification Method Using QFD}

The Quality Function Deployment (QFD) is applied to evaluate the potential of the B3 waste (used oil) in Pekanbaru area and is expected in this method will get the target to be achieved, namely B3 waste will be used as an alternative fuel diesel engine. In this method is also expected to be visible differences in results using diesel fuel with B3 waste (used oil) with potential savings on the economy and lead to environmentally friendly because indirectly reduce the negative impact of abuse B3 particularly used oil.

This method is not only considered the quality aspects and economic price but also pay attention to the environmental aspects into the matrix. These three aspects are each described in the Quality House can be seen in Figure 7.

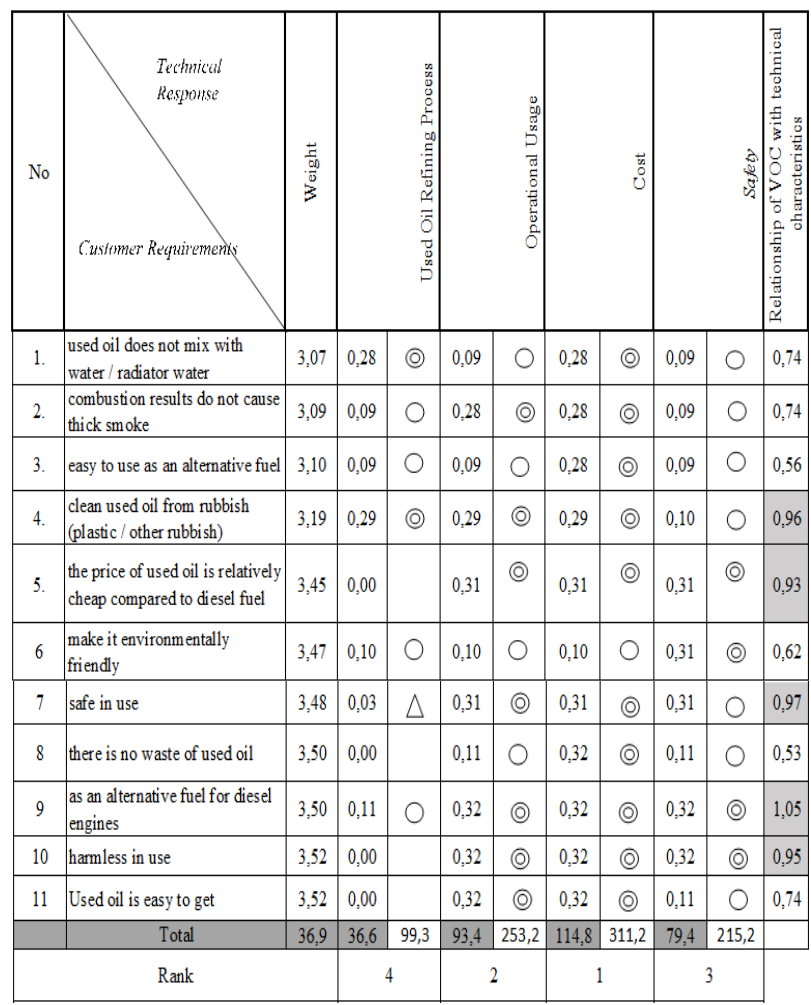

\begin{tabular}{|c|c|c|}
\hline \multicolumn{3}{|r|}{ Target Specifications } \\
\hline Rank & Informasi & \\
\hline \multirow{3}{*}{1} & \multirow{3}{*}{ Cost } & $\begin{array}{l}\text { 1. The price of used oil according to field observations the price per / liter of } \\
\text { used oil is Rp. } 2000.00 \text { / liter and the price can change according to the price } \\
\text { of new oil in the market }\end{array}$ \\
\hline & & $\begin{array}{l}\text { 2. Used oil fuel compared to diesel fuel, the test results show a much more } \\
\text { efficient difference using used oil fuel than diesel. Seen from the results of } \\
\text { the calculation of the comparison of fuel use. }\end{array}$ \\
\hline & & $\begin{array}{l}\text { 3. In the use of used oil fuel does not have a high special cost because used } \\
\text { oil is easy to obtain and the price is cheap, so this used oil has considerable } \\
\text { potential in the use of diesel fuel, especially at the cost }\end{array}$ \\
\hline \multirow{2}{*}{2} & \multirow{2}{*}{$\begin{array}{l}\text { Operational } \\
\text { Usage }\end{array}$} & $\begin{array}{l}\text { 1. Has an operational setup that is easy to use and does not take a long time to } \\
\text { operate this machine using used oil fuel }\end{array}$ \\
\hline & & $\begin{array}{l}\text { 2. Used oil does not need to be heated only needs to be deposited one night before } \\
\text { being put into the fuel glass for filtering before the fuel enters the combustion } \\
\text { chamber }\end{array}$ \\
\hline \multirow{2}{*}{3} & \multirow{2}{*}{ Safety } & $\begin{array}{l}\text { 1. Combustion results do not cause thick smoke so there is no excessive air } \\
\text { pollution. }\end{array}$ \\
\hline & & $\begin{array}{l}\text { 2. Used oil is not flammable if exposed to sparks from outside the engine so it is safe } \\
\text { to use. }\end{array}$ \\
\hline \multirow[b]{2}{*}{4} & \multirow[b]{2}{*}{$\begin{array}{l}\text { Used oil } \\
\text { refining }\end{array}$} & 1. Used oil does not need to be refined because it already has a fuel filter \\
\hline & & $\begin{array}{l}\text { 2. The initial filter is a filter that has a magnet so that when used oil is pumped into } \\
\text { the magnetic filter the fine iron grains can be filtered and then entered into the } \\
\text { ordinary fuel filter which will then enter the combustion chamber }\end{array}$ \\
\hline
\end{tabular}

Figure 7: House of quality

After the data processing of the results of the questionnaire was obtained ordering of priority needs of consumers based on their level of interest. The higher the value of each attribute, indicating that these attributes is getting overlooked by consumers. The quality attribute most important to the consumer based on its sequence based on the order that is the cost due to the nature of this case in terms of economic B3 used oil is very affordable and produce output that can be utilized for power generation of garage these consumers. The next sequence which is operational usage for B3 waste utilization of used oil is no need for heat treatment or other treatments against this oil before fuel made just filter powders of iron or sand that is on the oil itself, therefore the B3 waste utilization of used oil is very easy and does not take a long time to operate the machine using used oil fuel. As well, safety (security) and the latter refining used oil, in this study did not identify the security of the performance of the machine after using used oil, but for the use of used oil during the testing conditions of the engine continued to operate as usual and results of data collection was no error, and for refining used oil is only deposited during the night for use the next day, and if the used oil has been put into glass fuel further fuel pump is turned on to pump fuel into screening magnet and out into to filtering regular fuel before entering the chamber of combustion, in order to minimize the entry of sand or other iron powders. Comparison of voice of customer vs. technical characteristics can be seen in Figure 8.

From the comparison chart above shows that the value of the processing of the customer's desire to be highest at 10 attributes that is not harmful to use, and attributes 11 that used oil is obtained by weighting the value of 3.52 , but the value is not to be used as the target of this research but only to determine the average value of the collection to identify potential consumer desires B3 waste such as used oil. 
(C) 2012 ISOMAse, All rights reserved

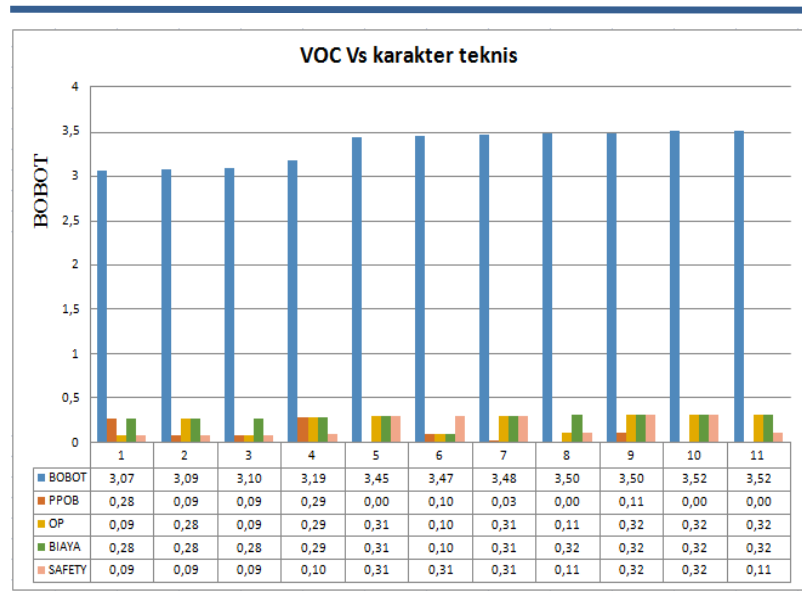

Figure 8: Ratio of VOC vs Technical Characteristics

In Figure 9, it can be seen that the highest value of the relationship between the voices of customer (VOC) with total technical character that is currently on the 9th attribute with a value of 1.05. This relationship was as an alternative fuel diesel engine and the second has a value of 0.96 on all four attributes that are clean used oil from waste plastic and so on. Then from these values concluded that the preferred targets in this study according to the customer's wishes is as diesel engine fuel and used oil that is free from a mixture of plastic waste and other waste and safe in use.

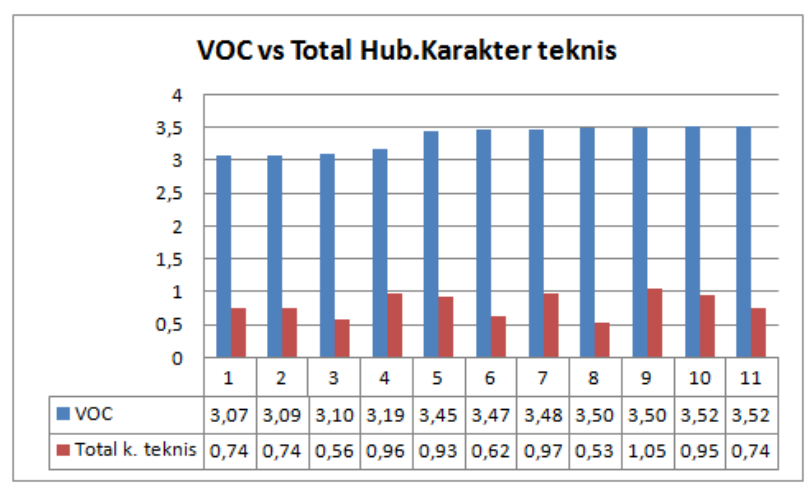

Figure 9: Ratio VOC vs total relation of technical characteristics

\subsection{Fuel Use Ratio}

The comparison of the cost of expenditure have used for machining operation for 2 minutes with a power output of 3 KW.

\section{a. Diesel fuel}

- Biodiesel fuel price of Rp. 5.150,-/liters

- The maximum power generated at $3050 \mathrm{~W}$

- Consumption of fuel used during operational within 2 minutes spend $52 \mathrm{ml}$ then:

$$
\frac{52 \mathrm{ml} \times 60 \text { minute }}{2 \text { minute }}=1560 \mathrm{ml} / \text { hour }
$$

- $\quad$ So $1560 \mathrm{ml} /$ hour to produce power equal to $3050 \mathrm{~W}$ 1.5 liters x Rp. 5.150,-/ liters = Rp. 7.725,

- The amounts to $1 \mathrm{KW}$ is Rp. 2.532,-

b. Used oil

- Used oil price of Rp. 2.000,-/liters
- The maximum power generated at $3050 \mathrm{~W}$

- Consumption of fuel used during operational within 2 minutes spent $40 \mathrm{ml}$ then:

$$
\frac{40 \mathrm{ml} \times 60 \text { minute }}{2 \text { minute }}=1200 \mathrm{ml} / \mathrm{hour}
$$

- So $1200 \mathrm{ml} /$ hour to produce power equal to $3050 \mathrm{~W}$ 1.2 liters x Rp. $2.000,-/$ liters = Rp. 2.400,-

- The costs incurred to $1 \mathrm{KW}$ is Rp. 787,-

\subsection{Grease Identification of Used Oil Properties}

This grease property was analyses in Mineral and Material Technology Laboratory of Chemical Engineering, Riau University. The density analyses were conducted in accordance to standard procedures.

a. Density

- Empty Pycnometer

- Water Pycnometer

- Used Oil Pycnometer

$=15.24$ gram $(0.01524 \mathrm{~kg})$

- Volume Pycnometer $=25.63 \operatorname{gram}(0.02563 \mathrm{~kg})$ $=24.26 \operatorname{gram}(0.02426 \mathrm{~kg})$ $=1 \times 10^{-5} \mathrm{~m}^{3}$

$$
\begin{aligned}
\rho & =\frac{m_{\text {water }}}{v} \\
& =\frac{(0,02563 \mathrm{~kg}-0,01524 \mathrm{~kg})}{1 \times 10^{-5} \mathrm{~m}^{3}} \\
& =1039 \mathrm{~kg} / \mathrm{m}^{3} \\
\rho & =\frac{m_{\text {used oil }}}{v} \\
& =\frac{(0,02426 \mathrm{~kg}-0,01524 \mathrm{~kg})}{1 \times 10^{-5} \mathrm{~m}^{3}} \\
& =902 \mathrm{~kg} / \mathrm{m}^{3}
\end{aligned}
$$

b. Viscosity

$$
\begin{aligned}
-\mathrm{t}_{\text {used oil }} & =2.9 \mathrm{~s} \\
-\quad \mathrm{t}_{\text {water }} & =0.5 \mathrm{~s} \\
-\quad \mu_{\text {weter }}= & 1.0 \times 10^{-3} \mathrm{~Pa} . \mathrm{s}\left(20^{\circ} \mathrm{C}\right) \\
v=\frac{\mu}{\rho} & \\
v_{\text {water }} & =\frac{\mu_{\text {water }}}{\rho_{\text {water }}} \\
v_{\text {water }} & =\frac{1,0 \times 10^{-3} \mathrm{~Pa} . \mathrm{s}}{997 \mathrm{~kg} / \mathrm{m}^{3}} \\
v_{\text {water }} & =\frac{1,0 \times 10^{-3} \mathrm{~kg} / \mathrm{m}^{3}}{997 \mathrm{~kg} / \mathrm{m}^{3}} \\
v_{\text {water }} & =1.003 \times 10^{-6} \mathrm{~m}^{2} / \mathrm{s} \\
\frac{v_{\text {water }}}{v_{\text {used oil }}} & =\frac{t_{\text {water }}}{t_{\text {used oil }}} \\
\frac{1,003 \times 10^{-6} \mathrm{~m}^{2} / \mathrm{s}}{v_{\text {used oil }}}=\frac{0,5 \mathrm{~s}}{2,9 \mathrm{~s}} & 0,5 \\
v_{\text {used oil }} & =\frac{2,9 \times\left(1,003 \times 10^{-6}\right) \mathrm{m}^{2} / \mathrm{s}}{0,5} \\
v_{\text {used oil }} & =5.8 \times 10^{-6} \mathrm{~m}^{2} / \mathrm{s}
\end{aligned}
$$

\subsection{CONCLUSION}

The conclusions are as follows:

a. Identification of potential research B3 is in quadrant one, which the recommendations of progressive $(+,+)$ to the 
value of internal factors of 0.9 and 0.7 . The value of external factors B3 states the used oil a high potential of opportunities in the use alternative fuel diesel engine, which have a positive impact in terms of both economic and environmental.

b. From the results of the HOQ manufacture concluded that the preferred targets in this study according to the customer's wishes is as diesel motor fuel and used oil. One is free from a mixture of plastic waste and others that is safe in use. From this conclusion is also proved that the use of waste fuels used oil B3 had chances were very helpful in terms of economy and environment.

c. According to the test results of fuel consumption between diesel and used oil in terms of cost were obtained Rp.2.532,-/KW for diesel fuel use, while the use of fuels used oil of Rp.787,-/KW. The costs are much lower compared to diesel fuel. Then for the results of its combustion was not pose a thick smoke that was different because the combustion of diesel using solar more visible than the smoke coming out of used oil.

\section{REFERENCE}

[1] Yohanes \& Fachrurrozi (2018). Modification of engine diesel for the used waste lubricant oil as an alternative fuel, Proceeding of Ocean, Mechanical and Aerospace Science and Engineering, 5(1).

[2] Widiyanto, D. (2018). Pemanfatan Limbah Oli Bekas Sebagai Bahan Bakar Pembantu Peledakan (Anfo) Pada Kegiatan Pertambangan Batu bara. Prosiding Seminar Nasional Teknologi Pengelolaan Limbah XIV Pusat Teknologi Limbah Radioaktif-BATAN, 1-8.

[3] Vlados, C. (2019). On a correlative and evolutionary SWOT analysis, Journal of Strategy and Management, 12(3), 347-363.

[4] Rangkuti, F. (2004). Analisis SWOT Teknik Membedah Kasus Bisnis. Jakarta: PT. Gradia.

[5] Phadermrod, B., Crowder, R.M. \& Wills, G.B. (2019). Importance-performance analysis based SWOT analysis, International Journal of Information Management, 44, 194-203.

[6] Liu, Y., Liu, T., Agveiwaa, A. \& Li, Y. (2018). A SWOT analysis of biodiesel production from waste cooking oil, IOP Conference Series: Earth Environmental Science, 17022136.

[7] Septiawan, H., Hariyadi \& Thohari, M. (2014). Analisis pengelolaan lingkungan pabrik kelapa sawit Batu Ampar- PT. Smart Tbk. Dalam Implementasi Indonesian Sustainable Palm Oil, Journal of Natural Resources and Environmental Management, 4(2), 136-144.

[8] Peraturan Menteri Negara Lingungan Hidup. Pemanfaatan Limbah Bahan Berbahaya dan Beracun. Jakarta. Nomor 02. 2008.

[9] Vita, E.S., Safitri, D.A.S. \& Hakim, A. (2014). Strategi pemasaran untuk meningkatkan penjualan PT. RPM dengan menggunakan analisis SWOT, Prosiding Seminar Nasional \& CFP IDRI.
[10] Chan, L.K., \& Wu, M.L. (2002). Quality function deployment: A literature review, European Journal of Operational Research, Vol.143(3), pp. 463-497.

[11] Yohanes, Satriardi, H.C., Susilawati, A. \& Arief, D.S (2016). Design of Coconut De-husking Machine Using Quality Function Deployment Method, Proceeding of Ocean, Mechanical and Aerospace -Science and Engineering-, 3, 506-510.

[12] Cohen, L. (1995). Quality Function Deployment: How to Make QFD Work for You. Addison Wesley Publishing Co.Erlangga, 1995.

[13] Bhaskar, T., Uddin, M.A., Muto A. Sakata, Y., Omura, Y., Kimura, K. \& Kawakami, Y. (2004). Recycling of waste lubricant oil into chemical feedstock or fuel oil over supported iron oxide catalysts, Fuel, 83(1), 9-15.

[14] Priambodo, B. (2001). Operasi dan Pemeliharaan Mesin Diesel. Jakarta: Erlangga.

[15] Suharsimi, A. (1996). Prosedur Penelitian Suatu Pendekatan Praktek. Jakarta: Rineka Cipta. 